\title{
STUDENTS' PERCEPTIONS, PROCESS AND PRODUCT IN A CSCL EXPERIENCE
}

\author{
Diego Vigueras ${ }^{1}$, María Cerrato Lara ${ }^{2}$, Francy Rodríguez ${ }^{3}$, Víctor Rampérez ${ }^{3}$, \\ Javier Soriano ${ }^{3}$, \& Guillermo Vigueras ${ }^{3}$ \\ ${ }^{1}$ Departamento de Psicología y Sociología, Universidad de Zaragoza (Spain) \\ ${ }^{2}$ Facultat d'Educació, Universitat Internacional de Catalunya (Spain) \\ ${ }^{3}$ Escuela Técnica Superior de Ingenieros Informáticos, Universidad Politécnica de Madrid (Spain)
}

\begin{abstract}
Following up students' progress in collaborative activities is a crucial element in the teaching task if we want to properly scaffold learning and assess students' performance. Considering this, a Computer Supported Collaborative Learning (CSCL) environment was created in the subject Middleware, devoted to the development of collaborative software projects delivered to undergraduates from Computer Engineering in a Spanish university. Students $(n=46)$ were asked to work in teams using the SCRUM methodology and the GitLab software. In order to analyse their individual performance, a Learning Analytics platform was created and an online survey was designed to complement the results obtained collecting students' perceptions. One of the aims in our project was to explore the relationships between students' outcomes and their perceptions about teamwork and the tools used. Specifically, we analysed the relationship between students' final mark, students' perceptions of teamwork and their SCRUM competence. Their sense of flow during the collaborative activity was measured as well. Results show correlations among these variables. Further discussion is provided around the students' perceptions as a key aspect for understanding students' behaviour and performance.
\end{abstract}

Keywords: Computer supported collaborative learning (CSCL), undergraduates, perceptions. collaboration, teamwork.

\section{Introduction}

This research arises from the teaching need to provide adequate follow-up to the collaborative work of engineers in training and, in particular, to solve one of the main difficulties in this monitoring, such as documenting the collaborative tasks carried out (Wise \& Schwarz, 2017). To this end, a Learning Analytics (LA) platform has been implemented, and this implementation has been studied from a multidimensional perspective, seeking to identify its possible impact on the effectiveness of the learning achieved, not only in the instrumental competence of the students, but also in its psychological, social and individual aspects.

LA can be defined as "the measurement, collection, analysis, and reporting of data about learners and their contexts, for purposes of understanding and optimizing learning and the environments in which it occurs (ECAR-ANALYTICS Working Group, 2015, p. 2). These tools are expected to allow teachers a more refined monitoring of students work, while also providing greater precision in evaluating the two main lessons learned from online collaboration.

The effectiveness of group learning in the training of computer engineering university students, and in their preparation for professional performance, has been widely studied (Hernández Sellés, González Sanmamed, \& Muñoz Carril, 2014, Zhan, 2008). By requiring not only collaborative learning, but learning to collaborate, group learning fosters active, constructive and reflective learning (Zariquiey Biondi, 2016; Zhan, 2008), while also developing much-needed interpersonal skills in the flexible working environments of the 21st century (Schwendimann, Beat A., De Wever, Bram, Hämäläinen, Raija, Cattaneo, 2018).

In recent years, in the university training of computer engineers, the curricula have been adapted to incorporate the learning of agile methodologies, due to their growth in the software industry as a means for collaborative work (Kropp \& Meier, 2013a). Agile methodologies are characterized by being iterative and incremental, with short work cycles, constant deliveries and a high level of interaction among team members (Dybå \& Dingsøyr, 2008; Kropp \& Meier, 2013b). These characteristics present a challenge both for professors and students since it is necessary to evaluate and to provide feedback, on individual and group level, on aspects such as use of the methodology, management of the tools and collaboration in teams (Mahnic, 2012). 
This learning context can be conceptually located within the Computer-Supported Collaborative Learning (CSCL), a multidisciplinary field focused on studying how technology and computers can improve and make collaborative work more efficient (Cheng, Yu, \& Li, 2013; Shawky, Badawi, Said, \& Hozayin, 2015). The literature on CSCL identifies as determining factors: the type of collaboration established, the collaborative model and the tools and support provided to students (e.g. Borges, Mizoguchi, Bittencourt, \& Isotani, 2018). On the other hand, although there are several terms related to online collaborative learning that are in some way interchangeable (Zhan, 2008), CSCL specificity relays in its emphasis on the collaborative online resources used (Wise \& Schwarz, 2017, p.427)

To face the challenge of monitoring the students, especially when using agile methodologies, the literature on CSCL recognizes the importance of an adequate teacher planning, able to take into consideration both the students' real capacity to collaborate, as well as providing an effective pedagogical use of the implied resources (e.g. Kropp \& Meier, 2013a; Walter, Tramontini, Fontana, Reinehr, \& Malucelli, 2013). In that sense, SCRUM methodology can be a good guide.

On the other hand, deepening in the factors that allow to understand and predict the positive results of students in virtual environments, in general, and in CSCL in the training of computer engineers, in particular, research in eLearning in the last decades has identified several variables, such as: self-efficacy (Muñoz et al. 2017), and specifically self-efficacy in relation to learning computer programming and online collaboration (e.g. Tek, Benli, \& Deveci, 2017), self-regulation (e.g. Chakraborty \& Muyia Nafukho, 2014), metacognition (e.g. Cocea \& Weibelzahl, 2006; Järvelä et al., 2016), implicit theories about their own capacities (e.g. Güeto Rubio, 2018), intrinsic motivation and the flow state (Cocea \& Weibelzahl, 2006; Cristea, 2017; Walter et al., 2013) and the influence of emotions, especially anxiety in groups. of online collaborative work (e.g. Syed-Abdullah, Holcombe, \& Gheorge, 200). In this paper we focus specifically on the study of the flow state.

\section{Design}

This study is part of a broader investigation devoted to analyse the effectiveness of the implementation of a Learning Analytics (LA) platform as a tool for teachers to monitor the CSCL of their students. For this research, a mixed parallel design has been chosen under the general form of a Design-Based Research (DBR). Our aim is to elaborate a framework useful as a guide to achieve a personalized follow-up in the scope of the CSCL. The purpose of this design is, firstly, to deepen the understanding of the CSCL in the context of software engineering and, secondly, to study the features of the instructional tool designed, in this case, the LA platform.

\section{Objectives}

This work is aimed to identify the effectiveness of online collaborative learning based on its determining factors, both social and individual. This is the reason why it has been explored the relationships between the students' results and their immersion in the work carried out. Our goal is to understand what social, individual psychological factors can be influencing students' CSCL. Specifically, we analyse the relationship between the students' final mark, students' perceptions of teamwork, students' perceptions of the tools employed and students' competence with SCRUM. Their sense of flow during the collaborative activity is measured as well.

Table 1 shows the research questions and related hypothesis in this design.

Table 1. Research questions and related hypothesis.

\begin{tabular}{ll}
\hline Research question & Hypothesis \\
\hline $\begin{array}{l}\text { How do students' perceptions about teamwork and } \\
\text { the tools employed influence their performance with }\end{array}$ & $\begin{array}{l}\text { Hypothesis 1: Better students' perceptions about teamwork and the } \\
\text { tools employed influence their performance with SCRUM within } \\
\text { the GitLab environment }\end{array}$ \\
$\begin{array}{l}\text { How do these variables affect the students' degree of } \\
\text { immersion in the work carried out in relation to their } \\
\text { performance? }\end{array}$ & $\begin{array}{l}\text { Hypothesis 2: Flow states in online collaboration correlates with } \\
\text { positive perceptions of the students towards the activity and the } \\
\text { tools used and with a better performance in the collaborative } \\
\text { activity. }\end{array}$ \\
\hline
\end{tabular}

\section{Methods}

This study has been carried out with the 46 students of the aforementioned Middleware subject. This subject, eminently practical and with a teaching load of 3 ETCs, is offered in the third year of the Computer Engineering Degree at the Polytechnic University of Madrid (UPM). According to the academic itinerary chosen previously by each student, previous experience with programming or online collaboration may be different for each student. 
To work on the two software development projects included in this course, a CSCL environment was developed based on the GitLab platform -a wikis-based software repository-, which has been adapted to implement concepts associated with SCRUM, an agile methodology widely adopted. Students were asked to work in teams of three or four freely formed by the same students.

For an initial descriptive exploration of the study, a questionnaire was developed. It was implemented online after the completion of the practices of the Middleware subject. The teacher of the subject was responsible for introducing and monitoring its completion. Those students doing their internships were sent a link to the electronic questionnaire to be answered outside class time.

The items of the questionnaire developed were organized in 7 sections (for this study we only used the items from Section 1 and 6):

- Presentation: students are informed about the purpose of the questionnaire and aspects about anonymity.

- Section 1: students' own perceptions of their expertise with tools for collaborative work, as well as about collaborative work and the tools to be used during the practices of the Middleware subject.

- Section 2: general self-efficacy of the students. Scale of general self-efficacy (Sanjuán Suárez, Pérez García, \& Bermúdez Moreno, 2000).

- Section 3: student's self-compassion. Spanish version of the Self-Compassion Scale (SCS) (Garcia-Campayo et al., 2014).

- Section 4: students' implicit theories about their learning.

- Section 5: students' level of anxiety. Spanish version of the Kuwait University Anxiety Scale (S-KUAS) (Abdel-Khalek, Tomás-Sabádo, \& Gómez-Benito, 2004).

- Section 6: students' flow state during the collaborative work. The Spanish version of the Flow State Scale (FSS, Jackson \& Marsh, 1996; Spanish version, Calvo, Castuera, Ruano, Vaíllo, \& Gimeno, 2008).

- Section 7: sociodemographic data as well as informing students about data protection.

Students' marks concerning their process and product elaborated during a collaborative activity were collected as well.

\section{Results}

In the following table, correlations among the variables analysed for our study can be observed:

Table 2. Correlations among variables.

\begin{tabular}{|c|c|c|c|c|c|c|}
\hline & & $\begin{array}{l}\text { Activity } \\
\text { mark }\end{array}$ & $\begin{array}{c}\text { SCRUM } \\
\text { competency }\end{array}$ & $\begin{array}{l}\text { Perceptions of tools for } \\
\text { collaboration }\end{array}$ & $\begin{array}{l}\text { Teamwork } \\
\text { perception }\end{array}$ & Flow \\
\hline \multirow{3}{*}{ Activity mark } & Pearson correlation & 1 & ,798** &, 270 &, 245 &, $376^{*}$ \\
\hline & Sig. (bilateral) & & ,000 & ,069 &, 101 &, 010 \\
\hline & $\mathrm{N}$ & 46 & 46 & 46 & 46 & 46 \\
\hline \multirow{3}{*}{$\begin{array}{l}\text { SCRUM } \\
\text { competency }\end{array}$} & Pearson correlation &, $798^{* *}$ & 1 &, $371^{*}$ & 155 &, $305^{*}$ \\
\hline & Sig. (bilateral) &, 000 & & ,011 & ,302 & ,039 \\
\hline & $\mathrm{N}$ & 46 & 46 & 46 & 46 & 46 \\
\hline \multirow{3}{*}{$\begin{array}{l}\text { Perceptions of } \\
\text { tools for } \\
\text { collaboration }\end{array}$} & Pearson correlation & ,270 &, $371^{*}$ & 1 &, $591^{* *}$ &, $491^{* *}$ \\
\hline & Sig. (bilateral) & ,069 & ,011 & & ,000 & ,001 \\
\hline & $\mathrm{N}$ & 46 & 46 & 46 & 46 & 46 \\
\hline \multirow{3}{*}{$\begin{array}{l}\text { Teamwork } \\
\text { perception }\end{array}$} & Pearson correlation & 245 &, 155 &, $591^{* *}$ & 1 &, $584^{* *}$ \\
\hline & Sig. (bilateral) &, 101 & ,302 &, 000 & &, 000 \\
\hline & $\mathrm{N}$ & 46 & 46 & 46 & 46 & 46 \\
\hline \multirow{3}{*}{ Flow } & Pearson correlation &, $376^{*}$ &, $305^{*}$ & $491^{* *}$ &, $584^{* * *}$ & 1 \\
\hline & Sig. (bilateral) & ,010 & ,039 & ,001 & ,000 & \\
\hline & $\mathrm{N}$ & 46 & 46 & 46 & 46 & 46 \\
\hline
\end{tabular}

**The correlation is meaningful at level 0,01 (bilateral)

* The correlation is meaningful at level 0,05 (bilateral) 
Adaptive perceptions of teamwork strongly correlates with positive perceptions of tools for collaboration The sense of flow along the collaborative activity strongly correlates with adaptive perceptions of teamwork and positive perceptions of tools for collaboration. To a less extent, it correlates with the activity mark and the SCRUM competency. Lastly, SCRUM competency strongly correlates with the activity mark and to a less extent with positive perceptions of tools for collaboration.

\section{Discussion}

The use of Learning Analytics (LA) is a highly promising research area in educational technology for supporting the teaching activity (Wise \& Schwarz, 2017). In this context, it is important for us to investigate the role of different factors in the learning process such as performance, competences or perceptions.

Our study shows that adaptive perceptions of teamwork and positive perceptions of the tools employed influence students' performance with SCRUM within the GitLab environment. Furthermore, it also shows that the flow state in online collaboration correlates with positive perceptions towards a collaborative activity, the tools used and with a better performance.

Although some studies address the flow state (Cocea \& Weibelzahl, 2006; Cristea, 2017; Walter et al., 2013), there is a gap in studies relating it with perceptions, process and products in a CSCL experience. It is interesting in our study how the sense of flow correlates more strongly with perceptions than with performance and competency. Therefore, it seems that individual perceptions play a key role in the sense of flow. However, when thinking of competencies, they correlate stronger with performance than with perceptions.

Considering that LA has to do with transversal learning of social skills and teamwork (Hernández-Sellés, González-Sanmamedy, \& Muñoz-Carril, 2015, page 151), our work brings some light into some aspects that show students' sense of flow along collaborative activities such as their individual perceptions (adaptive perceptions of teamwork and positive perceptions of tools for collaboration), process followed (the SCRUM competency) and product obtained (the activity mark). Future research should deep in these lines.

\section{Acknowledgements}

This work has been partially funded by Universidad Politécnica de Madrid through Education Innovation Project (IE1819.1003) and by Universitat Internacional de Catalunya (Spain).

\section{References}

Abdel-Khalek, A. M., Tomás-Sabádo, J., \& Gómez-Benito, J. (2004). Psychometric Parameters of the Spanish Version of the Kuwait University Anxiety Scale (S-KUAS). European Journal of Psychological Assessment, 20(4), 349-357.

Borges, S., Mizoguchi, R., Bittencourt, I. I., \& Isotani, S. (2018). Group Formation in CSCL: A Review of the State of the Art (Vol. 832). Springer International Publishing. http://doi.org/10.1007/978-3-31997934-2

Calvo, T. G., Castuera, R. J., Ruano, F. J. S., Vaíllo, R. R., \& Gimeno, E. C. (2008). Psychometric Properties of the Spanish Version of the Flow State Scale. The Spanish Journal of Psychology, 11(2), 660-669.

Chakraborty, M., \& Muyia Nafukho, F. (2014). Strengthening student engagement: What do students want in online courses? European Journal of Training and Development, 38(9), 782-802. http://doi.org/10.1108/EJTD-11-2013-0123

Cheng, X., Yu, Y., \& Li, Z. (2013). Facilitated Collaboration in CSCL based Undergraduate Course - A Longitudinal Case Study in China. Journal of Software, 8(1), 31-38. http://doi.org/10.4304/jsw.8.1.31-38

Cocea, M., \& Weibelzahl, S. (2006). Motivation - Included or Excluded from e-Learning. In IADIS International Conference on Cognition and Exploratory Learning in Digital Age, CELDA (pp. 435-437). Barcelona, Spain. Retrieved from http://209.85.129.132/search?q=cache\%3AiVXbCLBS4P0J\%3Aciteseerx.ist.psu.edu\%2Fviewdoc $\%$ 2Fdownload\%3Fdoi\%3D10.1.1.75.520\%26rep\%3Drep1\%26type\%3Dpdf+motivation+elearning $\& \mathrm{hl}=\mathrm{de} \& \mathrm{gl}=\mathrm{at}$

Cristea, A. I. (2017). Immersion in e-Learning. Workshop and Tutorial Proceedings of the 28th ACM Conference on Hypertext and Social Media (Hypertext'17), 7-10. Retrieved from CEUR-WS.org

Dybå, T., \& Dingsøyr, T. (2008). Empirical studies of agile software development: A systematic review. $\begin{array}{llll}\text { Information } \quad \text { and } & \text { Software } & \text { Technology, }\end{array}$ http://doi.org/10.1016/j.infsof.2008.01.006 
ECAR-ANALYTICS Working Group. (2015). The Predictive Learning Analytics Revolution: Leveraging Learning Data for Student Success. ECAR Working Group Paper. Louisville, CO.

Garcia-Campayo, J., Navarro-Gil, M., Andrés, E., Montero-Marin, J., López-Artal, L., \& Demarzo, M. M. P. (2014). Validation of the Spanish versions of the long (26 items) and short (12 items) forms of the Self-Compassion Scale (SCS). Health and Quality of Life Outcomes, 12(1), 4. http://doi.org/10.1186/1477-7525-12-4

Güeto Rubio, M. (2018). Mentalidad de crecimiento, motivación de logro y progreso académico en estudiantes de música de conservatorio. Universidad Internacional de La Rioja.

Hernández-Sellés, N., González-Sanmamedy, M., \& Muñoz-Carril, P.-C. (2015). El rol docente en las ecologías de aprendizaje: Análisis de una experiencia de aprendizaje colaborativo en entornos virtuales / Teacher's roles in learning ecologies: looking into collaborative learning in virtual environments. Profesorado. Revista de Currículum y Formación Del Profesorado, 19(2). Retrieved from http://www.ugr.es/local/recfpro/rev192ART9.pdf

Järvelä, S., Kirschner, P. A., Hadwin, A., Järvenoja, H., Malmberg, J., Miller, M., \& Laru, J. (2016). Socially shared regulation of learning in CSCL: understanding and prompting individual- and group-level shared regulatory activities.International Journal of Computer-Supported Collaborative Learning, 11(3), 263-280. http://doi.org/10.1007/s11412-016-9238-2

Kropp, M., \& Meier, A. (2013a). Teaching agile software development at university level. IMVS Fokus Report, 15-20. http://doi.org/10.1109/CSEET.2013.6595249

Kropp, M., \& Meier, A. (2013b). Teaching agile software development at university level: Values, management, and craftsmanship. Software Engineering Education Conference, Proceedings, (May), 179-188. http://doi.org/10.1109/CSEET.2013.6595249

Mahnic, V. (2012). A Capstone Course on Agile Software Development Using Scrum. IEEE Transactions on Education, 55(1). http://doi.org/10.1109/MS.2002.1032858

Muñoz Maldonado, S. I., Sánchez Medina, R., Enríquez Negrete, D. J., \& Rosales Piña, C. R. (2017). Contraste de Estudiantes Universitarios Presenciales y en Línea en un Curso Autogestivo: el Papel de la Autoeficacia y la Motivación. Hamut'Ay, 4(2), 7. http://doi.org/10.21503/hamu.v4i2.1467

Sanjuán Suárez, P., Pérez García, A. M., \& Bermúdez Moreno, J. (2000). Escala de autoeficacia general: datos psicométricos de la adaptación para población española. Psicothema, 12(2), 509-513. http://doi.org/10.1109/ICICI.2017.8365312

Schwendimann, Beat A.; De Wever, Bram; Hämäläinen, Raija; Cattaneo, A. A. P. (2018). The state-of-the-art of collaborative technologies for initial vocational education: A systematic literature review. International Journal for Research in Vocational Education and Training (IJRVET), 5(1), 19-41. http://doi.org/10.13152/IJRVET.5.1.2

Syed-Abdullah, S., Holcombe, M., \& Gheorge, M. (2006). The impact of an agile methodology on the well being of development teams. Empirical Software Engineering, 11(1), 143-167. http://doi.org/10.1007/s10664-006-5968-5

Walter, M., Tramontini, R., Fontana, R. M., Reinehr, S., \& Malucelli, A. (2013). Agile Processes in Software Engineering and Extreme Programming, 149, 310-318. http://doi.org/10.1007/978-3-64238314-4

Wise, A. F., \& Schwarz, B. B. (2017). Visions of CSCL : eight provocations for the future of the field. International Journal of Computer-Supported Collaborative Learning, 12, 423-467.

Zariquiey Biondi, F. (2016). Cooperar para aprender. Madrid: Ediciones SM. 